\title{
Management of sickle cell priapism with etilefrine
}

\author{
A D Gbadoé, Y Atakouma, K Kusiaku, J K Assimadi
}

\begin{abstract}
Intracavernous injections of etilefrine were effective in seven children with acute sickle cell priapism, and stuttering priapism resolved in five children after one to seven months of oral etilefrine. Compared with our previous reports in adults, etilefrine appears to be more effective in childhood.
\end{abstract}

(Arch Dis Child 2001;85:52-53)

Keywords: priapism; alpha adrenergic agonist; sickle cell anaemia

Priapism is a painful vaso-occlusive complication of sickle cell anaemia (SCA). Recently, the actuarial probability of young males with SCA experiencing priapism by 20 years of age was estimated at $89 \% .{ }^{1}$ For some years, treatment of priapism has included the use of $\alpha$ adrenergic agonists. ${ }^{2-4}$ Most published information concerns adults. We aimed to assess the results of this treatment in 11 children with SCA consecutively treated in Lomé-Tokoin's teaching hospital.

Division of Infectiology and Onco-hematology, Department of Pediatrics, University of Lomé, BP 8881, Lomé-Togo A D Gbadoé

Y Atakouma K Kusiaku

J K Assimadi

Correspondence to: Dr Gbadoé

adgbadoe@tg.refer.org

Accepted 15 March 2001

Table 1 Results of treatment of acute or stuttering priapism with oral etilefrine

\begin{tabular}{rllll}
\hline Patient no. & Outcome & $\begin{array}{l}\text { Treatment } \\
\text { duration }\end{array}$ & Side effects & Follow up \\
\hline 1 & No relapse & $1 \mathrm{mth}$ & None & $1 \mathrm{y}$ \\
2 & No relapse & $1 \mathrm{mth}$ & Agitation & $2 \mathrm{y}$ \\
3 & No relapse & $1 \mathrm{mth}$ & None & $3 \mathrm{y}$ \\
4 & No relapse & $1 \mathrm{mth}$ & None & $2 \mathrm{y}$ \\
5 & No relapse & $1 \mathrm{mth}$ & None & $4 \mathrm{y}$ \\
6 & No relapse & $1 \mathrm{mth}$ & None & $3 \mathrm{mth}$ \\
7 & Remission, relapse, cure in $4 \mathrm{mth}$ & $5 \mathrm{mth}$ & None & $4 \mathrm{y}$ \\
8 & Remission, relapse, cure in $6 \mathrm{mth}$ & $7 \mathrm{mth}$ & None & $3 \mathrm{y}$ \\
9 & Decrease in attacks, then cure in 3 mth & $4 \mathrm{mth}$ & None & $1 \mathrm{y}$ \\
10 & Cure in 1 mth & $1 \mathrm{mth}$ & None & $1 \mathrm{y}$ \\
11 & Remission, relapse, cure in $4 \mathrm{mth}$ & $5 \mathrm{mth}$ & None & $2.5 \mathrm{y}$ \\
\hline
\end{tabular}

relapse, we used $0.25 \mathrm{mg} / \mathrm{kg}$ twice a day of oral etilefrine for one month.

SP was treated with oral daily administration of $0.5 \mathrm{mg} / \mathrm{kg}$ etilefrine for one month. This was given in the evening to patients with nocturnal priapism; $0.25 \mathrm{mg} / \mathrm{kg}$ twice a day was given for priapism which occured both during the day and night. These patients also self administered (or parent administered) intracavernous injections to reverse painful episodes lasting more than one hour. In those whose attacks had not ceased after one month, or who relapsed after remission, treatment was continued until one month after eventual resolution. Safety of treatment was assessed by measuring blood pressure and by direct questioning about erectile function or any other apparent side effects.

\section{Results}

The age at onset of SP varied from 11 years to 15 years (mean 13 years). The duration of an attack of SP ranged from five minutes to three hours. The duration of evolution of SP ranged from one to nine months.

Five patients with AP were given intracavernous etilefrine with a delay ranging from four to 28 hours. This procedure was successful in producing immediate detumescence in all children after a single injection. Neither hydration nor analgesia were necessary. Intracavernous injections were not needed in the five cases of SP. All 11 patients received oral etilefrine: six to prevent relapse of AP (patients 1-6) and five for the curative treatment of SP (patients 7-11, table 1). No patients treated for prevention of AP relapsed. After one month of treatment, attacks decreased in one patient with SP, while four others remitted. Three of the latter relapsed two weeks to two months later, but prolonged remission was achieved in all after one to seven months of treatment. No serious immediate or long term side effects (particularly hypertension or erectile dysfunction) were observed, either with intracavernous injections or oral etilefrine. One patient experienced agitation which ceassed after dosage reduction.

\section{Discussion}

In our series, priapism attacks seemed less severe in intensity in children than in adults (for example, no need for intracavernous injections in all children, whereas eight of our 15 adults who presented with SP used intracavernous injections, personal communication). The delay to treatment of AP was relatively short (less than 28 hours) compared to the 
delays of longer than 30 hours observed in nine patients of 16 previously reported. ${ }^{3}$ We consider that this may explain the success in all those children who presented with $\mathrm{AP}$, as intracavernous etilefrine is not usually effective beyond the thirtieth hour of priapism, ${ }^{3}$ because of necrosis of erectile tissue. These long delays in seeking medical help may be related partly to the beliefs held by many of our patients. A recent survey revealed that $31.5 \%$ of patients with SCA in Lomé, thought that priapism was caused by a spell cast over a man who had committed adultery. ${ }^{5}$ Thus adults with priapism often attend hospital only after previously seeking treatment from traditional healers.

Children responded better to oral etilefrine than adults. In fact, remission was obtained in almost all children after one month of treatment, and prolonged remission was obtained in all five patients after one to six months, whereas half of the adults whom we have described previously did not respond to oral etilefrine. ${ }^{6}$ Home management of SP is effective for almost all adult patients using such means as a cold penile bath, physical exercise, distraction, or other activities. Some adults reported these methods as effective ${ }^{6}$; they were not carried out by the children, but we now advise suggesting them to children and their parents.

Preventing recurrent priapism with oral etilefrine seemed beneficial in our paediatric patients. In the series of paediatric SCA patients of Mantadakis and colleagues, ${ }^{4}$ where follow up oral therapy was not so structured as in our series, pseudoephedrine appeared to decrease the number of recurrent episodes. Nevertheless, we recommend multicentre, randomised, placebo controlled trials to assess the real benefit of oral $\alpha$ adrenergic agonists.

1 Mantadakis E, Cavender JD, Rogers ZR, et al. Prevalence of priapism in children and adolescents with sickle cell anemia. F Pediatr Hematol Oncol 1999;21:518-22.

2 Virag R, Bachir D, Lee K, Galacteros F. Preventive treatment of priapism in sickle cell disease with oral and self-administered intracavernous injection of etilefrine. Urology 1996;47:777-81.

3 Gbadoé AD, Akakpo-Vidah A, Pitché P, Assimadi JK. Priapisme drépanocytaire: prise en charge par injections intracaverneuses d'étiléfrine. Med Trop 2000;69:53-6.

4 Mantadakis E, Ewalt DH, Cavender JD, et al. Outpatient penile aspiration and epinephrine irrigation for young patients with sickle cell anemia and prolonged priapism. Blood 2000;95:78-82.

5 Gbadoé AD, Dogba A, Ségbéna AY, et al. Priapism in sickle cell anemia in Togo: prevalence and knowledge of this cell anemia in Togo: prevalence and

6 Gbadoé AD, Boronbossou S, Assimadi JK. Priapisme intermittent chronique drépanocytaire: prise en charge encore difficile. Presse Med 2000;29:898.

\section{1st Asia Pacific Forum on Quality Improvement in Health Care}

\section{Three day conference}

\section{Wednesday 19 to Friday 21 September 2001 \\ Sydney, Australia}

We are delighted to announce this forthcoming conference in Sydney. Delegate enquiries are welcome.

The themes of the Forum are:

- Improving patient safety

- Leadership for improvement

- Consumers driving change

- Building capacity for change: measurement, education and human resources

- The context: incentives and barriers for change

- Improving health systems

- The evidence and scientific basis for quality improvement.

Presented to you by the BMJ Publishing Group (London, UK) and Institute for Healthcare Improvement (Boston, USA), with the support of the the Commonwealth Department of Health and Aged Care (Australia), Safety and Quality Council (Australia), NSW Health (Australia), and Ministry of Health (New Zealand).

For more information contact: quality@bma.org.uk or fax +44 (0)20 73836869 